\title{
STRATEGI PENDIDIKAN ISLAM DALAM MENINGKATKAN KUALITAS SUMBER DAYA MANUSIA PERSPEKTIF ZAKIAH DARADJAT
}

\author{
'Neng Ulya, ${ }^{2 K h a l i d ~ R a m d h a n i ~}$ \\ I-2Universitas Singaperbangsa Karawang
}

\begin{abstract}
Abstrak
Realitas Pendidikan Islam saat ini bisa dibilang telah mengalami masa intellectual deadlock. Hal tersebut terjadi karena akibat dari minimnya upaya pembaharuan dan praktek pendidikan Islam sejauh ini masih memelihara warisan yang lama dan tidak banyak melakukan pemikiran kreatif, inovatif dan kritis terhadap isu-isu aktual. Selain itu, model pembelajaran pendidikan Islam terlalu menekankan pada pendekatan intelektualisme-verbalistik dan menegasikan pentingnya interaksi edukatif dan komunikasi humanistik antara guru-murid. Jenis penelitian yang dilakukan adalah penelitian kepustakaan (library research). Data-data yang dikumpulkan berasal dari tulisan-tulisan Zakiah Daradjat sebagai data utama (primer) dan sumber-sumber lainnya yang relevan dengan pembahasan sebagai data sekunder, baik itu berupa buku, majalah, artikel, makalah, hasil-hasil penelitian ataupun buletin yang ada kaitannya dengan penelitian ini.

Dari hasil penelitian pemikiran Zakiah Daradjat tentang strategi pendidikan Islam dalam meningkatkan kualitas sumber daya manusia (SDM), dapat di sederhanakan menjadi :Pertama, Konsep Strategi pendidikan Islam menurut Zakiah Daradjat untuk meningkatkan kualitas SDM terdiri dari dua model, yaitu strategi pendidikan yang bersifat makro dan strategi pendidikan yang bersifat mikro. Kedua, Manusia merupakan makhluk yang memiliki kemampuan istimewa di antara makhluk lainnya. Agar umat islam berperan aktif dan survive di era globaliasasi, Menpunyai keterampilan untuk melaksanakan peranan kemasyarakatan dengan baik, dan berakhlak mulia. dalam bidang sokial, politik, dan kemajuan iptek. Ketiga, Starategi pendidikan Islam yang digagas Zakiah Daradjat ,Potensi-potensi yang diberikan kepada manusia pada dasarnya merupakan petunjuk (hidayah) Allah yang diperuntukkan bagi manusia supaya ia dapat melakukan sikap hidup yang serasi dengan hakekat penciptaannya.

Kata Kunci: Strategi Pendidikan Islam, Zakiah Drajat, Sumber Daya Manusia
\end{abstract}

The reality of Islamic education today can be said to have experienced a period of intellectual deadlock. This happens because as a result of the lack of efforts to reform and practice Islamic education so far it still maintains the old heritage and does not do much creative, innovative and critical thinking on actual issues. In addition, the Islamic education learning model places too much emphasis on an intellectual-verbalistic approach and negates the importance of educative interactions and humanistic communication between teacher-students. The type of research conducted is library research. The data collected comes from the writings of Zakiah Daradjat as primary data and other sources relevant to the discussion as secondary data, whether in the form of books, magazines, articles, papers, research results or existing bulletins. relation to this research.

From the research results of Zakiah Daradjat's thoughts on Islamic education strategies in improving the quality of human resources (HR), it can be simplified into: First, the concept of Islamic education strategy according to Zakiah Daradjat to improve the quality of human resources consists of two models, namely educational strategies that are macro and micro education strategy. Second, Humans are creatures that have special abilities among other creatures. So that Muslims play an active role and survive in the era of globalization, have the skills to carry out social roles well, and have noble character. in the social, political, and science and technology fields. Third, the Islamic education strategy initiated by Zakiah Daradjat, the potentials given to humans are basically instructions (guidance) of Allah intended for humans so that they can carry out an attitude of life that is in harmony with the nature of their creation.

Keywords: Islamic Education Strategy, Zakiah Darajat, Human Resource 

Neng Ulya, Khalid Ramdhani, 202I, Strategi Pendidikan Islam Dalam Meningkatkan Kualitas Sumber Daya Manusia Perspektif Zakiah Daradjat

\section{A. PENDAHULUAN}

Sejak manusia menghendaki kemajuan dalam kehidupan, sejak itulah timbul gagasan untuk melakukan pengalihan, pelestarian, dan pengembangan kebudayaan melalui pendidikan. Oleh karena itu, dalam sejarah pertumbuhan masyarakat pendidikan senantiasa menjadi perhatian utama dalam rangka memajukan kehidupan generasi sejalan dengan tuntutan masyarakat. (H.M Arifin, 20I4: I2)

Arus itu bukanlah kawan maupun lawan bagi pendidikan Islam, melainkan sebagai dinamisator bagi 'mesin' yang bernama pendidikan Islam. Bila pendidikan Islam mengambil posisi anti global, maka 'mesin' tersebut akan tidak stationaire alias macet, dan pendidikan Islam pun mengalami intellectual shut down atau penutupan intelektual. Sebaliknya, bila pendidikan Islam terseret oleh arus global tanpa daya lagi identitas keislaman sebuah proses pendidikan akan dilindas oleh 'mesin' tadi. Karenanya pendidikan Islam menarik ulur arus global, yang sesuai ditarik bahkan dikemabangkan, sementara yang tidak sesuai diulur, dilepas atau ditinggalkan. Abd. Rachman Assegaf berpendapat sebagaimana mengutip Mastuhu, bahwa menutup diri atau bersikap eksklusif akan ketinggalan zaman, sedang membuka diri berisiko kehilangan jati diri atau kepribadian. (Akhmad Syarief Kurniawan, 2017)

Di sisi lain pendidikan Islam mengemban tugas penting, yakni bagaimana mengembangkan kualitas sumber daya manusia (SDM) agar umat Islam dapat berperan aktif dan tetap survive di era globalisasi. Dalam konteks ini Indonesia sering mendapat kritik, karena dianggap masih tertinggal dalam melakukan pengembangan kualitas manusianya. Padahal dari segi kuantitas Indonesia memiliki sumber daya manusia melimpah yang mayoritas beragama Islam.

Mengapa pengembangan kualitas sumber daya manusia menjadi sangat penting dan begitu urgent? Hal ini tak bisa dipungkiri mengingat abad XXI sebagai era globalisasi dikenal dengan situasinya yang penuh dengan persaingan (hypercompetitive situation). John Naisbitt dan Patricia Aburdene sebagaimana dikutip A. Malik Fadjar dalam Nurvita Octaviani (20II), pernah mengatakan bahwa terobosan paling menggairahkan dari abad XXI bukan karena teknologi, melainkan karena konsep yang luas tentang apa artinya manusia itu. Pengembangan kualitas SDM bukan persoalan yang gampang dan sederhana, karena membutuhkan pemahaman yang mendalam dan luas pada tingkat pembentukan konsep dasar tentang manusia serta perhitungan yang matang dalam penyiapan institusi dan pembiayaan.

Keberhasilan pembangunan terutama ditentukan oleh kualitas manusianya, bukan oleh melimpah-ruahnya kekayaan alam. Manusia merupakan titik sentral yang menjadi subyek dan perekayasa pembangunan serta sebagai obyek yang direkayasa dan menikmati hasil-hasil pembangunan. Sumber daya manusia pun (disamping pada kondisi-kondisi tertentu menjadi beban pembangunan) merupakan modal dasar pembangunan nasional yang memiliki potensi dan daya dorong bagi percepatan proses 
pelaksanaan pembangunan nasional. Dengan demikian, perilaku pembangunan, seyogyanya senantiasa mencerminkan peningkatan harkat dan martabat kemanusiaan demi peningkatan kualitas peradaban masyarakat bangsa dan negara. Di dalamnya diperlukan ketangguhan kualitas, watak dan moralitas manusia sebagai pelaku utamanya.

Upaya pengembangan dan peningkatan kualitas sumber daya manusia dapat dilakukan melalui berbagai jalur, diantaranya melalui pendidikan. Pendidikan ini merupakan jalur peningkatan kualitas sumber daya manusia yang lebih menekankan pada pembentukan kualitas dasar, misalnya keimanan dan ketakwaan, kepribadian, kecerdasan, kedisiplinan, kreativitas dan sebagainya.

Dalam hal pengembangan SDM, pendidikan memiliki nilai strategis dan mempunyai peran penting sebagai suatu investasi di masa depan. Karena secara teoretis, pendidikan adalah dasar dari pertumbuhan ekonomi, dasar dari perkembangan sains dan teknologi, mengurangi kemiskinan dan ketimpangan dalam pendapatan, dan peningkatan kualitas peradaban manusia pada umumnya. Nilai strategis pendidikan yang makro ini, menyimpulkan bahwa pendidikan menyimpan kekuatan luar biasa untuk menciptakan keseluruhan aspek lingkungan hidup dan dapat memberikan informasi paling berharga mengenai pegangan hidup di masa depan serta membantu anak didik mempersiapkan kebutuhan hidup yang esensial untuk menghadapi perubahan.

\section{B. METODE PENELITIAN}

Jenis penelitian yang dilakukan adalah penelitian kepustakaan (library research). Artinya, permasalahan dan pengumpulan data berasal dari kajian kepustakaan. Data-data yang dikumpulkan berasal dari tulisan-tulisan Zakiah Daradjat sebagai data utama (primer) dan sumber-sumber lainnya yang relevan dengan pembahasan sebagai data sekunder, baik itu berupa buku, majalah, artikel, makalah, hasil-hasil penelitian ataupun buletin yang ada kaitannya dengan penelitian penelitian ini. Hanya data yang betul-betul terkait dengan topik penelitian yang penulis cantumkan dalam penelitia ini. Jadi, tidak ada hasil wawancara dengan pakar pendidikan yang bersangkutan. (Arikunto, Suharsimi 2006 : 129)

\section{HASIL DAN PEMBAHASAN PENELITIAN}

\section{Biografi dan Riwayat Pendidikan Zakiah Daradjat}

Zakiah Daradjat lahir pada tanggal 6 November 1929, di kampung Kota Merapak, Kecamatan Ampek Angkek, Kotamadya Bukit Tinggi, Sumatra Barat. Ayahnya bernama $\mathrm{H}$. Daradjat Husain yang memiliki dua istri. Dari istrinya yang pertama, Rafi'ah, ia mempunyai 6 anak, dan Zakiah Daradjat adalah anak pertama dari keenam bersaudara. Sedangkan dari istrinya yang kedua, yaitu $\mathrm{Hj}$. Rasunah, ia dikaruniai 5 anak. Dengan demikian, dari dua istri $H$. Daradjat memiliki II putra. Sungguh pun 
Neng Ulya, Khalid Ramdhani, 202I, Strategi Pendidikan Islam Dalam Meningkatkan Kualitas Sumber Daya Manusia Perspektif Zakiah Daradjat

memiliki dua orang istri, ia kelihatannya cukup berhasil mengelola keluarganya. Hal ini terlihat dari kerukunan yang tampak dari putra-putrinya itu. Zakiah memperoleh perhatian yang besar dari ibu tirinya, sebesar kasih sayang ia terima dari ibu kandungnya. (Abuddin Nata, 2005 : 233)

H. Daradjat ayah landung Zakiah tercatat sebagai aktifis organisasi Muhammadiyah. Sedangkan ibu tirinya aktif di Sarikat Islam. Kedua organisasi yang berdiri pada akhir penjajahan Belanda ini tercatat sebagai organisasi yang cukup disegani masyarakat karena kiprah dan komitmennya pada perjuangan kemerdekaan Indonesia serta berhasil menangani dan mengelola pendidikan modern serta mengatasi problema sosial keagamaan dan sebagainya.

Sebagai aktifis yang kental sikap keagamaannya, memberikan dorongan yang kuat untuk memasukkan Zakiah ke sekolah Standart School Muhammadiyah di Bukit Tinggi. Di lembaga pendidikan inilah untuk pertama kalinya Zakiah Daradjat mendapatkan pendidikan agama serta ilmu pengetahuan dan pengalaman intelektual. Semenjak belajar di lembaga pendidikan ini, Zakiah Daradjat telah memperlihatkan minatnya yang cukup besar dalam bidang ilmu pengetahuan hal ini terlihat pada usianya yang baru 12 tahun, Zakiah Daradjat telah berhasil menyelesaikan pendidikan dasarnya dengan cukup baik, tepatnya pada tahun 194I.

Kecenderungan, bakat, dan minat Zakiah Daradjat untuk menjadi ahli agama Islam terlihat pula dalam mengikuti Kulliyatul Muballighat di Padang Panjang selama hampir 6 tahun. Di lembaga pendidikan ini Zakiah Daradjat memperoleh pendidikan agama secara mendalam. Namun demikian, perhatiannya terhadap bidang studi umum juga tetap besar. Hal ini terlihat pada aktifitas Zakiah Daradjat dalam memasuki Sekolah Menengah Pertama Negeri (SMPN) di kota yang sama. Di dua lembaga pendidikan ini, Zakiah Daradjat berhasil menyelesaikannya dengan tepat waktu, tepatnya tahun 1947. Pendidikan yang ia peroleh dari kedua lembaga ini benar-benar menjadi modal utama untuk melanjutkan pendidikannya di lembaga yang lebih tinggi. Sementara itu, budaya Minangkabau yang memberikan tanggungjawab yang lebih besar kepada perempuan dibandingkan dengan perempuan di daerah lain, juga memberikan andil yang cukup besar dalam diri Zakiah Daradjat. (Abuddin Nata, 2005 : 234)

Setelah menyelesaikan pendidikan dasar dan menengah pertama, Zakiah Daradjat melanjutkan ke sekolah Menengah Atas (SMA) Pemuda di Bukit Tinggi. Di lembaga pendidikan Menengah Atas ini Zakiah Daradjat memilih program B, yaitu program yang mendalami ilmu alam dan selesai pada tahun 195I. Masuknya Zakiah Daradjat pada SMA dengan program B tersebut, ternyata bukan merupakan petunjuk bahwa ia akan menjadi ahli ilmu umum, melainkan ilmu umum itu hanya sebagai pengetahuan yang suatu saat dapat digunakan sebagai dasar untuk memahami agama lebih mendalam lagi. 
Hal ini terlihat ketika Zakiah Daradjat memasuki Perguruan Tinggi yang ia pilih adalah Perguruan Tinggi Agama Islam Negeri (PTAIN) Yogyakarta. Bakat, minat, dan dasar pengetahuan agama dan umum yang cukup ternyata menjadi dasar bagi Zakiah Daradjat untuk menyelesaikan studinya dengan baik pada tahun 1955 dan berprestasi di perguruan tinggi tersebut. Prestasinya yang demikian itu selanjutnya membuka peluang bagi Zakiah Daradjat untuk mendapatkan tawaran melanjutkan ke Kairo. Tawaran tersebut tidak disia-siakan oleh Zakiah Daradjat. la mendalami bidang yang diminati, yaitu psikologi. Sesampainya di Kairo, Zakiah Daradjat mendaftarkan diri di Univeritas Ain Syam Fakultas Tarbiyah dengan konsentrasi Special Diplomator Education, dan Zakiah Daradjat diterima tanpa tes.

Dengan bekal pengetahuan dasar yang kuat serta didukung oleh ketekunan, semangat, dan bakatnya yang besar menyebabkan ia berhasil menyelesaikan studinya pada tahun 1964. Setelah itu Zakiah Daradjat mengikuti Program Magister pada jurusan spesialisasi kesehatan mental pada fakultas Tarbiyah di Universitas yang sama. Program ini ia selesaikan dalam waktu yang singkat, yaitu selama dua tahun dengan tesis yang berjudul, "Problematika Remaja Di Indonesia (Musykilat al-Murahaqah Fi Indonesia".

Untuk menuntaskan studi tingkat tingginya Zakiah Daradjat mengikuti Program Doktor (Ph.D) pada Universitas yang sama dengan mendalami psikologi, khususnya psikoterapi. Disertasi yang berhasil disusun dan dipertahankannya pada program doktornya ini adalah, "Perawatan Jiwa Untuk Anak-Anak atau Dirasah Tajribiyah li Taghayyur al-Lati Tathrau ala Syakhshiyah al-Athfal al-Musykil Infi'al fi Khilal Fithrah al-Ilaj al-Nafs Ghair al-Muwajjah an-Thariq al-La'b", dengan bimbingan Musthafa Fahmi dan Attia Mahmud Hanna. Dengan demikian Zakiah Daradjat telah menjadi seorang Doktor Muslimah pertama dalam bidang psikologi dengan spesialisasi psikoterapi.

\section{Konsep Strategi}

Pengertian strategi dalam kamus besar bahasa Indonesia "Strategi" sebagai rencana yang cermat mengenai kegiatan untuk mencapai sasaran khusus. Untuk itu diperlukan metode atau teknik tertentu sehingga kebijakan yang dihasilkan, akan optimal dalam rangka mencapai tujuan organisasi. melalui proses analisis perencanaan, perumusan pelaksanaan dan evaluasi serta pelaporan dan pertanggung jawaban atau disebut perencanaan strategis.

Hal ini dapat ditujukkan oleh adanya perbedaan konsep mengenai strategi selama 30 tahun terakhir. strategi adalah suatu alat yang sangat penting untuk mencapai keunggulan bersaing. strategi merupakan tindakan yang bersifat incremental (senantiasa meningkat) dan terus-menerus, dilakukan berdasarkan sudut pandang tentang apa yang diharapkan oleh pelanggan di masa depan (Rangkuti, 2004 : 4).

Tujuan dari sebuah strategi adalah suatu jalan untuk mencapai tujuan tertentu atau untuk mencapai target dan posisi strategis. Adapun 
Neng Ulya, Khalid Ramdhani, 202I, Strategi Pendidikan Islam Dalam Meningkatkan Kualitas Sumber Daya Manusia Perspektif Zakiah Daradjat

tujuan strategi pendidikan adalah suatu

perencanaan dan gagasan untuk mencapai tujuan pendidikan yang sesungguhnya sesuai dengan UU yang berlaku yaitu UU No.20 tahun 2003 pasal 3, yang berbunyi "Pendidikan nasional berfungsi mengembangkan kemampuan dan membentuk watak serta peradaban bangsa yang bermartabat dalam rangka mencerdaskan kehidupan bangsa, bertujuan untuk berkembangnya potensi peserta didik agar menjadi manusia yang beriman dan bertakwa kepada Tuhan Yang Maha Esa, berakhlak mulia, sehat, berilmu, cakap, kreatif, mandiri, dan menjadi warga negara yang demokratis serta bertanggung jawab”.

\section{Macam-macam Strategi}

Menurut pendapat Rangkuti (2004:6), strategi dapat dikelompokkan berdasarkan 3 (tiga) tipe strategi, yaitu :

\section{a. Strategi Manajemen}

Strategi manajemen meliputi strategi yang dapat dilakukan oleh manajemen dengan orientasi pengembangan strategi secara makro misalnya, strategi pengembangan produk, strategi penerapan harga, strategi pengembangan produk, strategi akuisi, strategi pengembangan pasar, strategi mengenai keuangan dan sebagainya.

\section{b. Strategi Investasi}

Strategi investasi merupakan kegiatan yang berorientasi pada investasi, misalnya, apakah perusahaan ini melakukan strategi pertumbuhan yang agresif atau berusaha mengadakan penetrasi pasar, strategi bertahan, strategi pembangunan kembali suatu divisi baru atau strategi diiventasi, dan sebagainya. c. Strategi Bisnis

Strategi bisnis ini juga disebut strategi bisnis secara fungsional karena bisnis ini berorientasi kepada fungsi-fungsi kegiatan manajemen, misalnya strategi pemasaran, strategi produksi atau operasional, strategi distribusi, strategi organisasi, dan strategistrategi yang berhubungan dengan keuangan.

\section{Pendidikan Islam}

Dengan diawali sejarah kehidupan manusia, Adam AS sebagai manusia pertama, proses pendidikan Islam telah dimulai. Allah SWT sebagai murabbi pertama yang mengajarkan kepada Adam AS. Dengan ilmu pengetahuan tentang nama-nama benda yang tidak diajarkan kepada makhluk lain, termasuk malaikat sekalipun. Selain pengetahuan yang diberikan kepadanya, telah diajarkan juga norma kehidupan guna memprotek fitrahnya sebagai makhluk dengan larangan Allah untuk menjauhi pohon Khuldi.

Dengan berkembangnya peradaban kehidupan manusia, sampainya pada masa Nabi Muhammad SAW sebagai pengembang pendidikan Islam telah membawa manusia lebih memahami jati dirinya, hal inilah yang diajarkan Allah kepada Al-Ma'sum. melalui wahyu pertamanya 5 ayat dari QS. Al-'Alaq yang berbunyi :

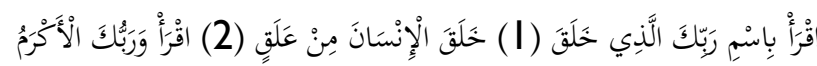

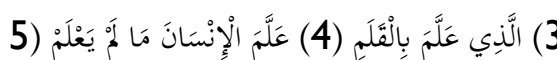

“I. Bacalah dengan (menyebut) nama Tuhanmu yang Menciptakan, 2. Dia telah menciptakan manusia dari segumpal darah. 3. Bacalah, dan 
Tuhanmulah yang Maha pemurah, 4. Yang mengajar (manusia) dengan perantaran kalam, 5. Dia mengajar kepada manusia apa yang tidak diketahuinya.” (Depag RI, 2004 : 597)

Menurut Shihab dalam Jaelani (2015) wahyu pertama ini adalah pengetahuan dasar tentang hakikat manusia dan sebagai way of life menyembah Tuhannya, dengan proses membaca seluruh alam ini dengan ucapan Iqra'. membaca yang dimaksudkan adalah men-tadabburi isi alam beserta isinya dan diri dari nabi, karena Sang Ummi tidak dapat menjawab perintah yang disampaikan oleh Jibril kepada Al-Ummi. Bukan berarti nabi tidak dapat membaca, hal tersebut karena untuk menjaga kepribadian seorang penyampai wahyu Allah. Perintah membaca disini bukan hanya ditujukan kepada Nabi Muhammad semata, namun untuk seluruh umat manusia sepanjang sejarahnya, realitas kalimat ini adalah kunci pembuka jalan kebahagiaan hidup di dunia dan akhirat.

Secara etimologi pendidikan Islam sering disebut dengan istilah tarbiyyah, ta'dîb, ta'lim, atau istilah lain yang maknanya pun memiliki keunikan makna tersendiri, rabba-yarbu-tarbiyah : bermakna tambah dan berkembang, kata tarbiyah berasal dari rabba-yurbi-tarbiyah : bermakna tumbuh dan menjadi besar/dewasa, rabba-yarubbu-tarbiyah : bermakna memperbaiki, menguasai urusan, memelihara dan merawat. Sehingga bila diambil dari kata kerjanya (rabba), pendidikan Islam memiliki arti menumbuhkan, mengembangkan, memelihara, membesarkan dan menjinakkan. (Abdul Mujib dan Yusuf Mudzakir, 2006 : II). a. Al-Tarbiyah

Kata Al-Tarbiyah yang bermakna seperti dimaksud diatas terdapat dalam Al-Qur'an surat Al-Isra' ayat 24 yang berbunyi :

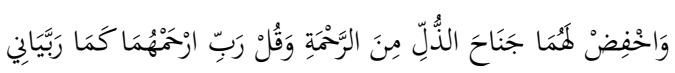

"Dan rendahkanlah dirimu terhadap mereka berdua dengan penuh kesayangan dan ucapkanlah : "Wahai Tuhanku, kasihilah mereka keduanya, sebagaimana mereka berdua telah mendidik aku waktu kecil". (Depag RI, 2004 : 284)

Dan Asy-Syu'ara ayat 18 :

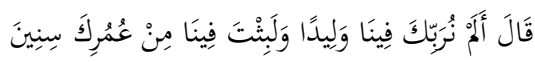

"Fir'aun menjawab : "Bukankah Kami telah mengasuhmu di antara (keluarga) Kami, waktu kamu masih kanak-kanak dan kamu tinggal bersama Kami beberapa tahun dari umurmu." (Depag RI, 2004 : 367)

Uraian di atas, secara filosofis, mengisyaratkan bahwa proses pendidikan Islam yang terkandung dalam Istilah Al-Tarbiyyah, memuat empat unsur, yaitu :

I) Memelihara dan menjaga fitrah anak didik menjelang dewasa,

2) Mengembangkan seluruh potensi menuju kesempurnaan,

3) Mengarahkan seluruh fitrah menuju kesempurnaan,

4) Melaksanakan pendidikan secara bertahap.

Istilah Al-Tarbiyah merupakan istilah yang paling popular untuk merujuk arti pendidikan karena menurut Athiyah Abrasyi, sebagaimana 
Neng Ulya, Khalid Ramdhani, 202I, Strategi Pendidikan Islam Dalam Meningkatkan Kualitas Sumber Daya Manusia Perspektif Zakiah Daradjat

dikutip oleh Ramayulis (2008 : 3), Al-Tarbiyah merupakan istilah yang mencakup keseluruhan kegiatan pendidikan. la adalah upaya yang mempersiapkan individu untuk kehidupan yang lebih sempurna dalam hal etika, sistematis dalam berpikir, memiliki ketajaman sempurna intuitif, giat dalam berkreasi, memiliki toleransi pada yang lain, berkompetisi dalam menangkap bahasa tulisan dan lisan serta memiliki beberapa ketrampilan.

Dengan demikian, makna pendidikan yang terkandung dalam istilah Al-Tarbiyah, dapat disimpulkan sebagai suatu proses pengembangan seluruh potensi, dengan menjaga dan memelihara serta mengarahkan seluruh fitrah dan potensi peserta didik menuju kebaikan dan kesempurnaan, yang dilakukan secara bertahap.

b. Al-Ta'lim.

Kata Al-Ta'lim dalam Ma'zumi, Syihabudin, dan Najmudin (2019) merupakan bentuk masdar dari kata 'allama, yang berarti mengajar yakni lebih bersifat pemberian atau penyampaian pengertian, pengetahuan dan Kata Al-Ta'lim dalam AlQur'an bisa dijumpai yaitu dalam Surat ArRahman ayat 2-4 yang berbunyi :

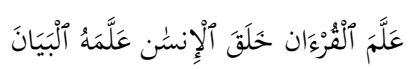

2. yang telah mengajarkan Al Quran. 3. Dia menciptakan manusia. 4. mengajarnya pandai berbicara. (Depag RI, 2004 : 53I)

Dan Al-Baqarah ayat 3I, yang berbunyi :

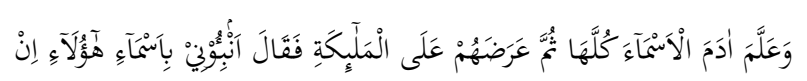$$
\text { كَنتْمْ صُدِقِينَ }
$$

“Dan Dia mengajarkan kepada Adam Nama-nama (benda-benda) seluruhnya, kemudian mengemukakannya kepada Para Malaikat lalu berfirman : "Sebutkanlah kepada-Ku nama bendabenda itu jika kamu mamang benar orang-orang yang benar!" (Depag RI, 2004 : 6)

Makna yang terkandung dalam ayat tersebut dalam konteks pendidikan Islam adalah upaya untuk mengaktualisasikan sifat-sifat kesempurnaan yang telah dianugerahkan oleh Allah kepada manusia. Pengertian Al-Ta'lim secara lebih luas tersirat dalam Al-Qur'an Surat Al-Baqarah ayat I5I, yang berbunyi :

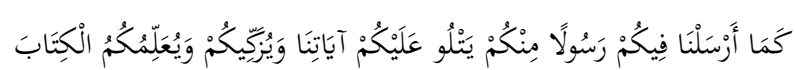

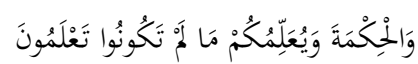

"Sebagaimana (kami telah menyempurnakan nikmat Kami kepadamu) Kami telah mengutus kepadamu Rasul diantara kamu yang membacakan ayat-ayat Kami kepada kamu dan mensucikan kamu dan mengajarkan kepadamu Al kitab dan AlHikmah, serta mengajarkan kepada kamu apa yang belum kamu ketahui." (Depag RI, 2004 : 23)

Berdasarkan firman Allah SWT tersebut, menurut Abdul Fattah Jalal (200I : 78) pendidikan tidak terbatas pada kemampuan membaca secara harfiah, tetapi lebih luas dari itu, yaitu membaca dengan perenungan yang sarat dengan pemahaman dan pada gilirannya melahirkan tanggung jawab moral terhadap ilmu yang diperoleh melalui bacaan itu. Konsep inilah yang digunakan oleh Rasulullah SAW. didalam mengatur dan mendidik para sahabat untuk mencapai tingkat tazkiyah (proses penyucian diri) yang membuat mereka berada dalam kondisi siap untuk mencapai tingkat Al-hikmah. 
Dapat diambil kesimpulan bahwa pendidikan yang terkandung dalam istilah AlTa'lim mengandung pengertian bahwa pendidikan merupakan proses yang didalamnya terkandung adanya transformasi pengetahuan-pengetahuan, pengertian, dan metode yang tidak hanya menekankan pada aspek kehidupan serta skill (ketrampilan) yang semuanya dihayati secara sungguh-sungguh didalam merealisasikannya dalam kehidupan sehari-hari.

c. Al-Ta'dib

At-ta'dib dalam Ma'zumi, Syihabudin, dan Najmudin (2019) merupakan bentuk masdar dari kata kerja addaba, juga diartikan mendidik yang lebih tertuju pada penyempurnaan akhlak budi pakerti. Menurut Al-Attas, sebagaimana dikuti Samsul Nizar, istilah Al-Ta'dib merupakan term yang paling tepat untuk diartikan pendidikan karena didalamnya mengandung arti ilmu, kearifan, keadilan, kebijaksanaan, pengajaran serta pengasuhan

\section{Muhammad Naquib Al-Attas,} sebagaimana dikutip oleh Ahmad Suyuthi (20II) secara berhati-hati menerjemahkan kata kerja "addabani" yang ada dalam hadits tersebut dengan "telah mendidikku", kemudian mengartikan perkataan "ta'dib" dengan "Pendidikan". Dari sini, terjemahan hadits tersebut adalah "Tuhan telah mendidikku dan menjadikan pendidikanku sebaik-baik pendidikan". Al-Attas, mengutip Ibnu Mansur dengan menyamakkan addaba dengan 'allama, pengertian yang memperkuat posisinya dalam menegaskan bahwa konsep pendidikan Islam yang betul adalah Al-Ta'dib. Muhammad Naquib
Al-Attas melanjutkan dalam bukunya konsep pendidikan islam, sebagaimana dikutip oleh Ahmad Suyuthi (20II), dengan gigih mempertahankan penggunaan istilah ta'dib untuk konsep pendidikan Islam, bukan tarbiyah atau ta'lim, dengan alasan bahwa dalam istilah ta'dib, mencakup wawasan ilmu dan amal yang merupakan esensi pendidikan Islam.

Berdasarkan batasan tersebut, maka AlTa'dib berarti pengenalan dan pengakuan yang secara berangsur-angsur ditanamkan dalam diri manusia (peserta didik) tentang tempat-tempat yang tepat dari segala sesuatu di dalam tatanan penciptaan. Dengan pendekatan ini, pendidikan akan berfungsi sebagai pembimbing ke arah pengenalan dan pengakuan tempat Tuhan yang tepat dalam tatanan wujud dan kepribadiannya.

Terlepas dari kegigihan argumen Naquib Al-Attas dan para ahli pendidikan Islam didalam mempertahankan ketiga term diatas (AlTarbiyah, Al-Ta'lim, Al-Ta'dib) sebagai konsep pendidikan Islam, dalam pembahasan ini penulis tidak akan memperdebatkan secara panjang lebar, karena sesungguhnya ketiga term tersebut merupakan satu kesatuan yang saling terkait, dalam arti bila pendidikan dinisbatkan kepada AlTa'dib, harus melalui pengajaran (Al-Ta'lim), sehingga dengannya ilmu dapat diperoleh, sedangkan agar ilmu dapat dipahami, dihayati, dan diamalkan, peserta didik memerlukan bimbingan (Al-Tarbiyah).

Oleh karena itu, pendidikan Islam secara etimologi harus mencakup ketiga term tersebut, yaitu Al-Tarbiyah, Al-Ta'lim dan Al-Ta'dib. Dengan demikian yang dimaksud pengertian 
Neng Ulya, Khalid Ramdhani, 202I, Strategi Pendidikan Islam Dalam Meningkatkan Kualitas Sumber Daya Manusia Perspektif Zakiah Daradjat

pendidikan Islam adalah adanya proses murrabi, Sumber Daya Manusia (SDM) Menurut mu'allim dan muaddib. Sedang secara Islam

terminologi menurut berbagai pakar pendidikan dapat dirumuskan sebagai berikut :

Proses transinternalisasi pengetahuan dan nilai Islam kepada peserta didik melalui upaya pengajaran, pembiasaan, bimbingan, pengasuhan, pengawasan, dan pengembangan potensinya, guna mencapai keselarasan dan kesempurnaan hidup di dunia dan akhirat. (Abdul Mujib dan Yusuf Mudzakir, 2006 : 28)

Menurut Muhaimin pendidikan dalam Islam dapat dimaknai secara sederhana sebagai berikut :

I. Pendidikan menurut Islam, atau pendidikan Islami adalah pendidikan yang dipahami dan dikembangkan dari ajaran dan nilai-nilai fundamental yang terkandung dalam Al-Qur'an dan Sunnah,

2. Pendidikan ke-Islam-an atau pendidikan agama Islam, yakni upaya mendidik agama Islam atau ajaran Islam dan nilai-nilainya agar menjadi pandangan dan sikap hidup seseorang (way of life),

3. Pendidikan dalam Islam, atau proses dan praktek penyelenggaraan pendidikan yang berlangsung dan berkembang dalam sejarah umat Islam, dalam arti proses bertumbuh kembangnya Islam dan umatnya, baik Islam sebagai Agama, ajaran, maupun sistem budaya dan peradaban sejak zaman Nabi Muhammad SAW sampai sekarang. (Muhaimin, 2002 : 29-30).

Manusia diciptakan oleh Allah sebagai penerima dan pelaksana ajaran sehingga ia ditempatkan pada kedudukan yang mulia. Untuk mempertahankan kedudukannya yang mulia dan bentuk pribadi yang bagus itu, Allah melengkapinya dengan akal dan perasaan yang memungkinkannya menerima dan mengembangkan ilmu pengetahuan dan membudayakan ilmu yang dimilikinya. Ini berarti bahwa kedudukan manusia sebagai makhluk yang mulia itu karena akal dan perasaan, ilmu pengetahuan dan kebudayaan yang seluruhnya dikaitkan kepada pengabdian pada Pencipta. (Zakiah Daradjat, 1996 : 3)

Potensi-potensi yang diberikan kepada manusia pada dasarnya merupakan petunjuk (hidayah) Allah yang diperuntukkan bagi manusia supaya ia dapat melakukan sikap hidup yang serasi dengan hakekat penciptaannya. Sejalan dengan upaya pembinaan seluruh potensi manusia, Muhammad Quthb berpendapat bahwa Islam melakukan pendidikan dengan melakukan pendekatan yang menyeluruh terhadap wujud manusia, sehingga tidak ada yang tertinggal dan terabaikan sedikitpun, baik dari segi jasmani maupun segi rohani,baik kehidupannya secara mental, dan segala kegiatannya di bumi ini. Islam memandang manusia secara totalitas, mendekatinya atas dasar apa yang terdapat dalam dirinya, atas dasar fitrah yang diberikan Allah kepadanya, tidak ada sedikitpun yang diabaikan dan tidak memaksakan apapun selain apa yang dijadikannya sesuai dengan fitrahnya. 
Pendapat ini memberikan petunjuk dengan jelas bahwa dalam rangka mencapai pendidikan Islam mengupayakan pembinaan seluruh potensi secara serasi dan seimbang. (Nata, Abuddin, (997: 5I)

Dari penjabaran di atas dapat dimengerti bahwa pengembangan SDM sangat penting, tak hanya dari sudut ilmu pengetahuan dan teknologi. Namun, tak kalah pentingnya adalah dimensi spiritual dalam pengembangan SDM. Kualitas SDM tidak akan sempurna tanpa ketangguhan mental-spiritual keagamaan. Sumber daya manusia yang mempunyai dan memegang nilai-nilai agama akan lebih tangguh secara rohaniah. Dengan demikian akan lebih mempunyai tanggung jawab spiritual terhadap ilmu pengetahuan serta teknologi. Sumber daya manusia yang tidak disertai dengan kesetiaan kepada nilai-nilai keagamaan, hanya akan membawa manusia ke arah pengejaran kenikmatan duniawi atau hedonisme belaka. Dan jika semangat hedonisme sudah menguasai manusia, bisa diramalkan yang terjadi adalah eksploitasi alam sebesar-besarnya tanpa rasa tanggung jawab dan bahkan penindasan manusia terhadap manusia lain.

\section{Biografi Zakiah Daradjat}

Zakiah Daradjat lahir pada tanggal 6 November 1929, di kampung Kota Merapak, Kecamatan Ampek Angkek, Kotamadya Bukit Tinggi, Sumatra Barat. Ayahnya bernama $\mathrm{H}$. Daradjat Husain yang memiliki dua istri. Dari istrinya yang pertama, Rafi'ah, ia mempunyai 6 anak, dan Zakiah Daradjat adalah anak pertama dari keenam bersaudara. Sedangkan dari istrinya yang kedua, yaitu $\mathrm{Hj}$. Rasunah, ia dikaruniai 5 anak. Dengan demikian, dari dua istri $H$. Daradjat memiliki II putra. Sungguh pun memiliki dua orang istri, ia kelihatannya cukup berhasil mengelola keluarganya. Hal ini terlihat dari kerukunan yang tampak dari putra-putrinya itu. Zakiah memperoleh perhatian yang besar dari ibu tirinya, sebesar kasih sayang ia terima dari ibu kandungnya. (Abuddin Nata, 2005 : 233)

H. Daradjat ayah kandung Zakiah tercatat sebagai aktifis organisasi Muhammadiyah. Sedangkan ibu tirinya aktif di Sarikat Islam. Kedua organisasi yang berdiri pada akhir penjajahan Belanda ini tercatat sebagai organisasi yang cukup disegani masyarakat karena kiprah dan komitmennya pada perjuangan kemerdekaan Indonesia serta berhasil menangani dan mengelola pendidikan modern serta mengatasi problema sosial keagamaan dan sebagainya.

Sebagai aktifis yang kental sikap keagamaannya, memberikan dorongan yang kuat untuk memasukkan Zakiah ke sekolah Standart School Muhammadiyah di Bukit Tinggi. Di lembaga pendidikan inilah untuk pertama kalinya Zakiah Daradjat mendapatkan pendidikan agama serta ilmu pengetahuan dan pengalaman intelektual. Semenjak belajar di lembaga pendidikan ini, Zakiah Daradjat telah memperlihatkan minatnya yang cukup besar dalam bidang ilmu pengetahuan hal ini terlihat pada usianya yang baru 12 tahun, Zakiah Daradjat telah berhasil menyelesaikan 
Neng Ulya, Khalid Ramdhani, 202I, Strategi Pendidikan Islam Dalam Meningkatkan Kualitas Sumber Daya Manusia Perspektif Zakiah Daradjat

pendidikan dasarnya dengan cukup baik, tepatnya pada tahun 1941.

Kecenderungan, bakat, dan minat Zakiah Daradjat untuk menjadi ahli agama Islam terlihat pula dalam mengikuti Kulliyatul Muballighat di Padang Panjang selama hampir 6 tahun. Di lembaga pendidikan ini Zakiah Daradjat memperoleh pendidikan agama secara mendalam. Namun demikian, perhatiannya terhadap bidang studi umum juga tetap besar. Hal ini terlihat pada aktifitas Zakiah Daradjat dalam memasuki Sekolah Menengah Pertama Negeri (SMPN) di kota yang sama. Di dua lembaga pendidikan ini, Zakiah Daradjat berhasil menyelesaikannya dengan tepat waktu, tepatnya tahun 1947. Pendidikan yang ia peroleh dari kedua lembaga ini benar-benar menjadi modal utama untuk melanjutkan pendidikannya di lembaga yang lebih tinggi. Sementara itu, budaya Minangkabau yang memberikan tanggungjawab yang lebih besar kepada perempuan dibandingkan dengan perempuan di daerah lain, juga memberikan andil yang cukup besar dalam diri Zakiah Daradjat. (Abuddin Nata, 2005 : 234) Setelah menyelesaikan pendidikan dasar dan menengah pertama, Zakiah Daradjat melanjutkan ke sekolah Menengah Atas (SMA) Pemuda di Bukit Tinggi. Di lembaga pendidikan Menengah Atas ini Zakiah Daradjat memilih program B, yaitu program yang mendalami ilmu alam dan selesai pada tahun 1951. Masuknya Zakiah Daradjat pada SMA dengan program B tersebut, ternyata bukan merupakan petunjuk bahwa ia akan menjadi ahli ilmu umum, melainkan ilmu umum itu hanya sebagai pengetahuan yang suatu saat dapat digunakan sebagai dasar untuk memahami agama lebih mendalam lagi.

Hal ini terlihat ketika Zakiah Daradjat memasuki Perguruan Tinggi yang ia pilih adalah Perguruan Tinggi Agama Islam Negeri (PTAIN) Yogyakarta. Bakat, minat, dan dasar pengetahuan agama dan umum yang cukup ternyata menjadi dasar bagi Zakiah Daradjat untuk menyelesaikan studinya dengan baik pada tahun 1955 dan berprestasi di perguruan tinggi tersebut. Prestasinya yang demikian itu selanjutnya membuka peluang bagi Zakiah Daradjat untuk mendapatkan tawaran melanjutkan ke Kairo. Tawaran tersebut tidak disia-siakan oleh Zakiah Daradjat. la mendalami bidang yang diminati, yaitu psikologi. Sesampainya di Kairo, Zakiah Daradjat mendaftarkan diri di Univeritas Ain Syam Fakultas Tarbiyah dengan konsentrasi Special Diplomator Education, dan Zakiah Daradjat diterima tanpa tes.

Dengan bekal pengetahuan dasar yang kuat serta didukung oleh ketekunan, semangat, dan bakatnya yang besar menyebabkan ia berhasil menyelesaikan studinya pada tahun 1964. Setelah itu Zakiah Daradjat mengikuti Program Magister pada jurusan spesialisasi kesehatan mental pada fakultas Tarbiyah di Universitas yang sama. Program ini ia selesaikan dalam waktu yang singkat, yaitu selama dua tahun dengan tesis yang berjudul, "Problematika Remaja Di Indonesia (Musykilat al-Murahaqah Fi Indonesia".

Untuk menuntaskan studi tingkat tingginya Zakiah Daradjat mengikuti Program 
Doktor (Ph.D) pada Universitas yang sama dengan mendalami psikologi, khususnya psikoterapi. Disertasi yang berhasil disusun dan dipertahankannya pada program doktornya ini adalah, "Perawatan Jiwa Untuk Anak-Anak atau Dirasah Tajribiyah li Taghayyur al-Lati Tathrau ala Syakhshiyah al-Athfal al-Musykil Infi'al fi Khilal Fithrah al-Ilaj al-Nafs Ghair al-Muwajjah an-Thariq al-La'b", dengan bimbingan Musthafa Fahmi dan Attia Mahmud Hanna. Dengan demikian Zakiah Daradjat telah menjadi seorang Doktor Muslimah pertama dalam bidang psikologi dengan spesialisasi psikoterapi.

\section{Konsep Pendidikan Islam dalam Perspektif Zakiah Daradjat}

Menurut Prof. Dr. Hj. Zakiah Daradjat, hakikat pendidikan mencakup kehidupan manusia seutuhnya. Pendidikan Islam yang sesungguhnya tidak memperhatikan satu segi saja, seperti segi akidah, ibadah atau akhlaknya saja, melainkan mencakup seluruhnya, bahkan lebih luas dari pada itu semua. Dengan kata lain pendidikan Islam memiliki perhatian yang lebih luas dari ketiga aspek tersebut. Hal ini menjadi titik tekan bagi Prof. Dr. Hj. Zakiah Daradjat, karena baik pendidikan Nasional maupun pendidikan Islam pada umumnya hanya memfokuskan pada salah satu aspek saja. (Abuddin Nata, 2005 : 242)

Lebih lanjut ia mengatakan bahwa pendidikan Islam mencakup semua dimensi manusia sebagaimana ditentukan oleh ajaran Islam. Pendidikan Islam juga menjangkau kehidupan di dunia dan kehidupan di akhirat secara seimbang. Pendidikan Islam memberikan perhatian pada semua aktifitas manusia serta mengembangkan hubungan antara dirinya dengan orang lain. Pendidikan Islam juga berlangsung sepanjang hayat, mulai dari manusia sebagai janin dalam kandungan ibunya sampai berakhirnya hidup di dunia ini.

Dalam hal ini, Zakiah Daradjat lebih tegas lagi menyatakan bahwa mulai umur kurang lebih dari 7 tahun, perasaan anak-anak terhadap Tuhan telah berganti dengan cinta dan hormat serta hubungannya dipenuhi oleh rasa iman. Fitrah yang dimaksud di sini yaitu potensi untuk menjadi Muslim dan untuk menjadi musyrik atau potensi itu tidak dapat diubah, maksudnya kecenderungan untuk menjadi baik dan sekaligus menjadi buruk itu tidak akan diubah oleh Tuhan. Secara sempit fitrah di sini adalah potensi untuk beragama, keinginan beragama, juga potensi untuk tidak beragama.

Kecenderungan adalah ciptaan Allah. Maksudnya, memang demikian manusia diciptakan Allah. Apa dan siapa sebenarnya manusia itu. Manusia adalah ciptaan Allah. la berkembang di pengaruhi oleh pembawaan dan lingkungannya, ia berkecenderungan beragama. Itulah antara lain hakikat wujud manusia. Selain itu, manusia adalah makhluk utuh yang terdiri atas jasmani, akal dan rohani sebagai potensi pokok.

Pemikiran Zakiah Daradjat tersebut memperlihatkan pandangannya tentang pendidikan yang bersifat integralistik dan komprehensif, yaitu mencakup seluruh dimensi, eksistensi, susbtansi, dan relasi manusia. 
Neng Ulya, Khalid Ramdhani, 202I, Strategi Pendidikan Islam Dalam Meningkatkan Kualitas Sumber Daya Manusia Perspektif Zakiah Daradjat

Menurutnya, konsep pendidikan yang demikian itu akan terwujud bila proses dan pelaksanaan pendidikan berjalan secara terus-menerus dengan dasar bahwa pendidikan bukan hanya sekedar proses belajar dan mengajar di sekolah belaka, melainkan berlangsung di berbagai lingkungan secara simultan. Dengan kata lain, pendidikan bukan hanya berlangsung di sekolah, melainkan juga di lingkungan yang lebih luas.

Lebih lanjut Zakiah Daradjat menggambarkan bahwa pendidikan Islam di ibaratkan seperti pertumbuhan dan perkembangan bunga-bunga, dimana potensipotensi tersebut berada pada benih. Kemudian berkembang menjadi bunga yang matang dan mekar. Dengan gambaran tersebut, anak didik adalah ibarat benih yang mengandung potensipotensi dasar yang tersembunyi dan tidak kelihatan. Sedangkan guru dapat diibaratkan seperti tukang kebun yang dengan kasih sayang, tanggung jawab, dan pemeliharaannya dengan cermat dapat membuka rahasia potensi-potensi yang tersembunyi. Pendidikan adalah proses mengajar berkebun dan proses berkebun itu sendiri. Dengan cara demikian dapat diketahui dan dipahami keunggulan-keunggulan yang tidak tampak menjadi tampak jelas.

Dengan dasar pemikiran tersebut, pendidikan Islam mengembangkan potensi fisik dengan kurikulum yang mengarah pada pembinaan dan pemeliharaan fisik para siswa. Aspek fisik ini menjadi demikian penting karena untuk pertama kalinya yang dilihat dari diri seseorang adalah kesehatan fisik jasmaninya.
Melalui jasmani yang sehat, maka kesehatan aspek lainnya diharapkan dapat diwujudkan.

Pandangan Zakiah Daradjat tentang perlunya kesehatan fisik sejalan dengan pandangan yang terdapat dalam Al-Qur'an dan al-Sunnah. Al-Qur'an adalah ajaran yang mengutamakan keseimbangan antara dunia akhirat, lahir batin, material spiritual, jasmani dan rohani (mental). (Zakiah Daradjat, 1982 : 9)

Berbagai batasan telah dibuat oleh para ahli tentang kesehatan rohani atau mental. Ada yang berpendapat bahwa sehat mental adalah terhindar dari gangguan dan penyakit kejiwaan (batasan ini banyak mendapat sambutan di kalangan psikiatri). Ada yang berpendapat bahwa kesehatan mental adalah kemampuan menyesuaikan diri dalam menghadapi masalah dan kegoncangan-kegoncangan biasa. Adapula yang mengatakan bahwa kesehatan mental harus mengandung keserasian fungsi-fungsi jiwa disamping itu ada pula yang berpendapat bahwa sehat mental adalah kemampuan merasakan kebahagiaan, kekuatan, dan kegunaan harga dirinya.

Al-Qur'an tidak mengenal adanya dikotomi antara keduanya. Karena kesehatan jasmani menjadi syarat dan diperlukan untuk mendukung kesehatan rohani, dan sebaliknya kesehatan rohani diperlukan untuk mendukung kesehatan jasmani. Untuk itu di dalam Al-Qur'an setiap ajaran yang mengarahkan pada kesehatan rohani, sekaligus mengandung misi kesehatan jasmani. Contohnya pelaksanaan ibadah sholat merupakan pekerjaan yang bersifat rohani, tapi akan memberi pengaruh terhadap kesehatan 
jasmani. Karena orang yang akan mengerjakan shalat disyaratkan harus bersih baik badan, pakaian, maupun tempat. Keharusan memiliki kebersihan ini adalah agar tertanam jiwa menyukai kebersihan, dan kebersihan merupakan pangkal kesehatan. Demikian pentingnya menjaga keseimbangan antara kesehatan jasmani dan rohani, maka Rasulullah SAW melarang seseorang beribadah secara berlebih- lebihan yang dapat menimbulkan kelelahan fisik dan menimbulkan penyakit.

Konsep Zakiah Daradjat dalam Meningkatkan Kualitas Sumber Daya Manusia

Selain mengemukakan strategi pendidikan Islam di atas, Zakiah Daradjat juga memaparkan wacana reorientasi pendidikan agama Islam yang berkaitan erat dengan pengembangan SDM, namun tidak termasuk dalam strategi di atas. la berpen dapat bahwa pendidikan Islam seharusnya mempunyai orientasi yang dapat mengembangkan SDM. Dalam hal ini ia mengemukakan tiga orientasi bagi pendidikan agama (Islam).

\section{Membangun Motivasi/Etos Kerja}

Agama Islam membimbing manusia untuk mencapai kebahagiaan di dunia dan di akhirat. Kebahagiaan di akhirat itulah kebahagiaan sejati dan kekal selama- lamanya, kebahagiaan di dunia bersifat sementara dan hanyalah alat untuk mencapai kebahagiaan sejati di akhirat namun ibarat ladang tempat menanam untuk memetik hasilnya di akhirat.
Kebahagiaan di dunia terjadi dalam bentuk terhindar dari segala yang mengancam dan mencelakakan hidup seperti penganiayaan, ketidakadilan, bencana, siksaan, kerusuhan, kedzaliman, pemerasan, dan segala macam penyakit dan marabahaya. Kebahagiaan jenis ini diberikan oleh Tuhan kepada manusia karena beriman dan beramal. Kebahagiaan akhirat terjadi dalam bentuk terhindar dari siksaan, baik di dalam kubur maupun pada hari akhirat sebelum dan sesudah menjalani pengadilan untuk surga dan neraka.

Ada dua syarat utama untuk kebahagiaan itu, yaitu iman dan amal. Iman adalah kepercayaan kepada Allah SWT, rasul, malaikat, kitab, hari kiamat, dan qadha dan qadar. Semua ini berkaitan dengan kebahagiaan manusia di akhirat. Inilah syarat utama. Syarat kedua ialah amal. Amal ialah perbuatan, tindakan, tingkah laku termasuk yang lahir dan batin, yang nampak dan tidak nampak, amal jasmani ataupun amal hati. Ada dua jenis amal yaitu amal ibadah (devotional act), yaitu amal yang khusus dikerjakan untuk membersihkan jiwa bagi kehidupan jiwa itu sendiri. Yang kedua inilah amal muamalat (non-directed act) yaitu segala amal yang berkaitan dengan hubungan manusia dengan manusia lain, seperti amal dalam perekonomian, kekeluargaan, warisan, hubungan kenegaraan, politik, pendidikan, sosial, kebudayaan, dan lain-lain. Ibadah ialah makanan ruhani sedangkan amal muamalat ialah makanan jasmani.

Inti pendidikan agama yang dapat memberikan motivasi kerja bagi setiap individu 
Neng Ulya, Khalid Ramdhani, 202I, Strategi Pendidikan Islam Dalam Meningkatkan Kualitas Sumber Daya Manusia Perspektif Zakiah Daradjat

dan masyarakat ialah iman dan amal. Karena

hanya itulah menurut sistem kepercayaan Islam yang dapat memberikan kebahagiaan kepada manusia dan dapat menghindarkannya dari kecelakaan di dunia dan di akhirat. Jadi, orientasi baru pendidikan agama ialah iman dan amal ke arah pembentukan masyarakat yang bermotivasi. (Zakiah Daradjat, 199I : 233)

\section{Membangun Disiplin Kerja}

Pembentukan masyarakat yang memiliki motivasi saja tidak cukup, motivasi kerja itu perlu dibimbing dan dikawal untuk ditujukan ke suatu arah tertentu, misalnya ke arah tujuan pembangunan. Motivasi perlu dikawal, diatur, diarahkan, disusun, dan lain-lain supaya bergerak menuju ke arah yang dituju, misalnya pembangunan. Itulah disiplin.

Disiplin tak hanya memiliki makna sempit, menyekat, mengendalikan dan menahan, tetapi makna disiplin menurut Zakiah Daradjat ialah melatih, mendidik, dan mengatur atau hidup teratur. Jadi, kalau motivasi beriringan istilah Zakiah Daradjat bergandeng bahu memang sudah tepat atau ideal. Karena yang pertama bergerak dengan kuat dan cepat manakala yang kedua mengatur dan melatih agar motivasi mempunyai arah dan tujuan tertentu.

Dalam konteks pendidikan agama, ada beberapa hal yang sangat berkaitan dengan disiplin, misalnya :
a) Sembahyang (shalat lima waktu) sehari semalam,
b) Puasa dalam bulan ramadhan,
c) Ibadah shalat sunah dan puasa sunah,

d) Konsep amanah yang memiliki makna pemberian tuhan kepada manusia termasuk kekayaan, ilmu pengetahuan, kekuasaan dan lain-lain harus pula dianggap sebagai tanggung jawab besar.

Pendidikan Islam sepatutnya menitikberatkan praktek ibadah dalam membentuk disiplin anak-anak di sekolah. Pengajaran yang terlalu menitikberatkan aspek kognitif dari pelajaran agama sekedar untuk lulus ujian sudah terlambat (out to date). Sekarang yang diperlukan adalah penghayatan pendidikan agama itu untuk membentuk masyarakat yang bermotivasi dan berdisiplin. (Zakiah Daradjat, 1991 : 235)

\section{Internalisasi Nilai-nilai}

Masalah penghayatan (internalitation) bukan hanya pada pendidikan agama saja, tetapi pada semua aspek pendidikan. Pendidikan akan menjadi dangkal jika hanya ditujukan untuk memperoleh ilmu (knowledge) terutama yang berkenaan dengan fakta (pengetahuan) dan kemahiran (skill). Pendidikan seperti ini tidaklah terlalu rumit karena tidak terlalu banyak melibatkan aspek nilai. Tetapi, sebaliknya pembelajaran sikap yang melibatkan nilai biasanya berasal dari cara kemasyarakatan yang diperoleh pelajar semasa kecil.

Nilai itu mestinya mempunyai model, yang bermakna tempat nilai itu melekat supaya dapat disaksikan bagaimana nilai itu beroperasi. Ambillah sebuah nilai seperti kejujuran. Menurut Zakiah Daradjat, nilai ini bersifat mujarrad (abstract). Supaya nilai yang bernama kejujuran itu dapat disaksikan beroperasi, maka nilai itu 
harus melekat pada suatu model, misalnya pada seorang guru, bapak, atau seorang kawan. Inilah sebagian yang perlu wujud untuk penghayatan nilai. Oleh karena itu, pendidikan agama merupakan pendidikan ke arah penghayatan agama, maka orientasi pendidikan agama haruslah ditinjau kembali agar sesuai dengan tujuan tersebut. (Zakiah Daradjat, I99I : 236)

Itulah tiga orientasi pendidikan agama Islam yang dikemukakan oleh Zakiah Daradjat. Ketiga orientasi tersebut mencerminkan bahwa pendidikan tak cukup dipelajari secara teori saja. Pendidikan agama Islam harus bisa mengejawantahkan nilai-nilai ajaran Islam dalam kehidupan sehari-hari, kapan dan dimanapun. Pendidikan Islam harus menjadi spirit bagi manusia untuk mengembangkan SDM-nya guna meraih kehidupan yang baik dan layak di dunia. Namun, pendidikan Islam juga harus menjadi pengontrol segala tindakan manusia agar dalam meraih tujuan hidup yang layak tersebut tetap dengan memegang teguh nilai-nilai Islam sehingga ia dapat mempertanggungjawabkan tugas dan fungsi sebagai khalifah di muka bumi.

\section{KESIMPULAN}

Konsep Strategi pendidikan Islam menurut Zakiah Daradjat untuk meningkatkan kualitas SDM terdiri dari dua model, yaitu strategi pendidikan yang bersifat makro dan strategi pendidikan yang bersifat mikro. Strategi yang bersifat makro terdiri dari tiga komponen utama, yaitu pertama, tujuan pendidikan Islam yang mencakup pembentukan insan shaleh dan masyarakat shaleh. Kedua, dasar-dasar pokok pendidikan Islam yang menjadi landasan kurikulum terdiri dari 8 aspek, yaitu : keutuhan, keterpaduan, kesinambungan, keaslian, bersifat ilmiah, bersifat praktikal, kesetiakawanan, dan keterbukaan. Ketiga, prioritas dalam tindakan yang meliputi penyerapan semua anak-anak yang mencapai usia sekolah, kepelbagaian jalur perkembangan, meninjau kembali materi dan metode pendidikan, pengukuhan pendidikan agama, administrasi dan perencanaan, dan kerja sama regional dan antar negara di dalam dunia Islam.

\section{DAFTAR PUSTAKA}

Akhmad Syarief Kurniawan, 2017, Tantangan Pendidikan Islam Dan Budaya Lokal pada Era Globalisasi di Indonesia, Tarbawiyah, Jurnal Ilmiah Pendidikan : Vol. OI No.I.

Arifin, Muhammad, IImu Pendidikan Islam : Tinjauan Teoritis Dan Praktik Berdasarkan Pendekatan Interdisipliner, Jakarta, Bumi Aksara, 2014

Daradjat, Zakiah, Islam dan Kesehatan Mental, Jakarta, Gunung Agung, 1982

Perawatan Jiwa Untuk

Anak,Jakarta :Bulan Bintang , 1973 , Kesehatan Mental, Jakarta,

Gunung Agung, I 983 , Metodik Khusus Pengajaran

Agama Islam, Jakarta, Bumi Aksara, 1995 , Pendidikan Agama Dalam

Pembinaan Mental,Jakarta : Bulan Bintang, 1975

, Pendidikan Islam dalam 
Neng Ulya, Khalid Ramdhani, 202I, Strategi Pendidikan Islam Dalam Meningkatkan Kualitas Sumber Daya Manusia Perspektif Zakiah Daradjat

Keluarga dan Sekolah, Jakarta, Ruhana, 1995

Depdikbud, Kamus Besar Bahasa Indonesia, Jakarta, Balai Pustaka, 2002

Fattah, Nanang, Ekonomi dan Pembiayaan Pendidikan, Bandung, Remaja Rosda Karya, 2001

Jaelani, Dian Iskandar, 2015, Pendidikan Islam Dalam Meningkatkan Kualitas Sumber Daya Manusia: Konsep Dan Strategi Implementatif, Jurnal Pendidikan Islam Edukasi, Vol. 3 No.

2, STAI Muhammadiyah Tulungagung

Latif, Abdul, Pengembangan Sumber Daya Manusia yang Berkualitas Menghadapi Era Pasar Bebas, Jakarta, DPP HIPPI, 1996

Ma'zumi, Syihabudin, dan Najmudin, Pendidikan Dalam Perspektif Al-Qur'an Dan Al-Sunnah : Kajian Atas Istilah Tarbiyah, Taklim, Tadris, Ta'dib dan Tazkiyah, Jurnal Tarbawy, Universitas Sultan Ageng Tirtayasa, Banten, Vol. 6 No.2, 2019.

Mujib, Abdul dan Yusuf Mudzakir, IImu Pendidikan Islam, Jakarta, Kencana Prenada Media, 2006

Nata, Abuddin, Filsafat Pendidikan Islam, Jakarta, Logos Wacana IImu, 200I.
Nata, Abuddin, Tokoh-Tokoh Pembaruan Pendidikan Islam di Indonesia, Jakarta, PT. Raja Grafindo Persada, 2005

Nurvita Octaviani , 2011, Konsep Pendidikan Islam Perspektif Abdul Malik Fadjar, Skripsi, Fakultas, Institut Agama Islam Negeri Sunan Ampel, Fakultas Tarbiyah, Jurusan Pendidikan Agama Islam : Surabaya

Pamungkas, Sri Bintang, Dengan Sumber Daya Manusia (SDM) dan IPTEK Mengatasi Kemiskinan, Mencapai Kemandirian, Jakarta, Seminar dan Sarasehan Teknologi, 1993

Ramayulis, IImu Pendidikan Islam, Jakarta, Kalam Mulia, 2008.

Resya Oktavia, 2017, Pembaharuan Pendidikan Islam Menurut Muhaimin, Skripsi, Fakultas Tarbiyah dan Keguruan Universitas Negeri Raden Intan Lampung.

Suyuthi, Ahmad, Ta'dib Sebagai Upaya Rekonstruksi Pendidikan Islam Perspektif Syed Naquib Al-Attas Jurnal Al Hikmah, Volume I, No. 2, 20II

Suharsimi, Arikunto, 2006. Prosedur Penelitian Suatu Pendekatan Praktik, Jakarta, Rineka Cipta, 